\title{
СИСТЕМА ПІДРИМКИ ПРИЙНЯТТЯ РІШЕННЯ ДЛЯ СИСТЕМИ ДОКУМЕНТООБІГУ НА ОСНОВІ МЕХАНІЗМУ ІНТЕЛЕКТУАЛЬНОГО АНАЛІЗУ
}

\footnotetext{
Анотація: Стаття присвячена механізмам підвищення достовірності прийняття рішення в процесах управління організацією за допомогою комп'ютерних автоматизованих систем. Розглянуто основні особливості та класифікацію систем підтримки прийняття рішень (СППР). Запропоновано механізм підвищення ефективності контролю за документообігом оснований на інтелектуальному аналізі параметрів передачі інформації та даних документа.

Ключові слова: системи підтримки прийняття рішень, документообіг, інтелектуальний аналіз, автоматизовані системи, управління організацією.
}

\section{Вступ}

На сучасному підприемстві, або будь-якій організації існуе великий обсяг інформації. Ї̈̈ обробка та аналіз приводять до додаткових витрат часу та зусиль. Це стосуеться як різноманітної документації так і даних про працівників, їх прав, а точніше обов'язків на робочому місці. Більшість процесів в організації полягають у прийнятті рішень, виправленні помилок, перевірці правильності введення даних. За таких умов управління потребуе впровадження комп'ютерних технологій, які б автоматизували робочий процес та сприяли б прийняттю правильного рішення.

Прикладом таких систем являються системи підтримки прийняття рішення СППР. За допомогою статистичного аналізу, оперування як старими так і новими даними ними виконуеться формування результату. Достовірність та точність отримання даних можливо корегувати в процесі навчання, що викликає необхідність застосування спеціальних механізмів інтелектуального характеру.

\section{Сучасні СППР для підтримки електронного документообігу}

Системи підтримки прийняття рішення - інструмент взаємодії в організації, який поєднуе різноманітні технології серед яких бази даних, інтерактивні комп'ютерні системи, імітаційне керування та технології основані на принципах штучного інтелекту. Залежно від поставленого завдання всі ці складові можуть бути інтегровані в систему.

За допомогою СППР можливо вирішити як структуровані так і неструктуровані завдання, які крім того можуть включати і велику кількість параметрів.

(c) В.В. Стешин, Л.В. Сидоренко, 2013 


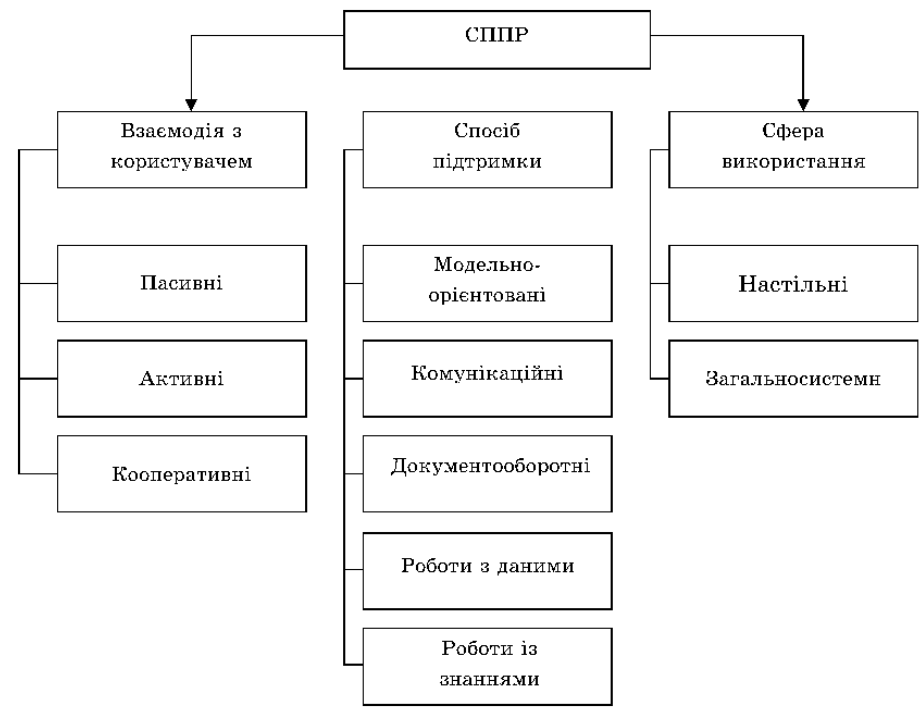

Рис. 1 - Класифікація сучасних СППР

На рис. 1 зображений поділ СППР за трьома категоріями: за взаємодією з користувачем, за способом підтримки та за сферою використання.

В процесі взаємодії з користувачем СППР може надавати результат певного аналізу та обробки даних. Такі СППР називаються пасивними оскільки не дають конкретної рекомендації або пропозиції, щодо подальших дій. В іншому випадку вони називаються активними і беруть безпосередню участь в розробці правильного рішення. Останніми в даній категорії є кооперативні СППР крім вище сказаного вони мають можливість налаштування. Користувач може доробляти та вдосконалювати пропозицію наданою системою.

Залежно від сфери роботи СППР діляться на: модельнооріентовані , комунікаційні, роботи з даними, документами та знаннями. Модельно-орієнтовані використовують в роботі доступ до статичних, фрінансових чи інших моделей. Головним їх завданням $є$ забезпечення легкого доступу до моделей і маніпулювання ними. В процесі взаємодії двох, або більше користувачів СППР виконуе роль комунікаційного зв'язку між ними. Тобто дана група користувачів може мати спільне завдання і тоді СППР включають модулі планування, відправлення повідомлень, спільного розв'язання проблем та ін., що підвищують ефективність групової роботи.

Інші три різновиди СППР оріентовані на різні інформаційні 
джерела. Це можуть бути дані, документи та знання. В першому випадку СППР мають доступ до баз даних організації. Вони використовують в роботі не тільки внутрішні, але і зовнішні дані та можуть працювати як з великою кількістю інформації так і аналізувати прості файлові системи (XML). За їх допомогою менеджери обробляють дані для ідентифікації фактів і отримання висновків у вигляді графічних зображень (діаграм, графіків, трендів), а також дозволяють здійснювати пошук, сортування, аналіз та прийняття обгрунтованого рішення на основі великою кількості інформації.

На відміну від попереднього типу, СППР документообігу орієнтованих на документи працюють з неструктурованою інформацією, що збережена в різних електронних форматах. Вони призначені для того, щоб допомагати менеджерам збирати неструктуровані документи та керувати ними. Крім простого пошуку та сортування СППР даного типу виконують важливу роль в документообігу всередині організації. Залежно від обов'язків та ролі працівників в організації СППР може виконувати затвердження документів по всій ієрархії відповідальних осіб, вести статистику часу обробки документів та ін.

Останнім в переліку е СППР, які працюють на основі знань. Вони е специфічними системами, які приймають рішення на основі здобутих фрактів, спеціалізованої інформації, експертних висновках. Добування даних е процесом фільтрування великих обсягів даних для отримання таких, що відповідають контексту задачі. Інструментальні засоби, які використовуються для побудови орієнтованих на знання систем, інколи також називають методами інтелектуальної підтримки прийняття рішень. Вони можуть використовуватися для створення комбінованих СППР: орієнтованих на дані, або орієнтованих на знання [1].

Оскільки системи підтримки прийняття рішення можуть використовуватися як одним так і групою користувачів їх поділяють на два типи: загальні - це такі які дозволяють опрацьовувати інформацію багатьма користувачами в межах організації, мережі та ін. та настільні - зосередження на роботі з одним користувачем, як правило локальні системи.

\section{Специфіка реалізації СППР в електронному документообігу}

Системи підтримки прийняття рішення представляються різними авторами по різному. В їхній архітектурі часто пропонуються додаткові модулі, що відіграють певну роль в поставлених задачах. В [2] запропоновано узагальнену архітектуру, що складається з чотирьох частин, зображену на рис. 2 .

Перша складова - це система керування даними. Вона відповідає за керування даними, виконує функцію доступу до даних, зокрема: забезпечуе безпеку баз даних, обробку запитів, управлін- 


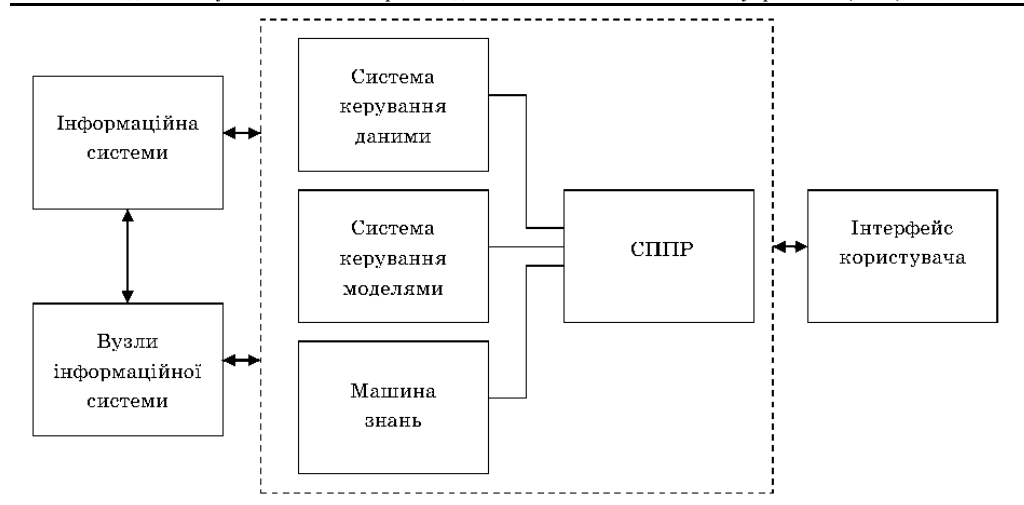

Рис. 2 - Узагальнена структура СППР

ня одночасним доступом до даних, резервне копіювання, оптимізації запитів та підтримку різних форматів даних. Другим елементом СППР е система керування моделями. Дана складова відповідає за опрацювання структур, моделей та зв'язок з даними. Важливу роль в СППР відіграє машина знань. Цей елемент відповідае за накопичення, збір та використання даних в процесі аналізу. Його присутність в загальній архітектурі СППР дозволяє охарактеризувати систему, як експертну, що містить знання та аналітичні здібності і здатна робити логічні висновки на основі цих знань, тим самим забезпечуючи вирішення специфічних завдань (консультування, навчання, діагностика, тестування, проектування тощо) без присутності експерта (спеціаліста в конкретній проблемній галузі) [3,4]. Останнім $е$ інтерфейс користувача, який створює зв'язок СППР з користувачем. Він дає можливість зручного управління та відображення результату виданого СППР.

Одним з важливих завдань, яке виконують СППР - це перевірка правильності документообігу в організації. Даний процес е важливим у виконанні управління. За визначенням документообіг це комплекс робіт з документами: прийом, реєстрація, розсилання, контроль виконання, формування справ, зберігання і повторне використання документації, довідкова робота та ін. [5] В свою чергу системи автоматизації документообігу (системи електронного документообігу) забезпечують процес створення, управління доступом і розповсюдження електронних документів в комп'ютерних мережах, а також забезпечують контроль над потоками документів в організації.

Наприклад в процесі документообігу документів, які відіграють управлінську роль відзначають такі етапи: розгляд документа, виконання, погодження, затвердження, реєстрація, ознайомлення, доручення [6,7] . Для їх контролю та автоматизації викори- 
стовуються методи СППР. 3 точки зору організації алгоритм колективної роботи, оскільки за виконання даних завдань відповідає група працівників, починається з резолюції керівника організації, далі документ передається працівникам із списку відповідальних осіб, погоджується, або повертається на доопрацювання. У разі позитивного рішення документ попадає на реєстрацію і йому присвоюється реєстраційний номер. Потім документ передається всім за списком для ознайомлення і доручається на виконання також певним особам. В системах електронного документообігу все відбувається за таким же алгоритмом, але даний процес супроводжуеться звітністю, аналізом та правильністю виконання всіма учасниками. Крім того в системах електронного документообігу з контролем СППР є можливість призначення завдань не тільки певним виконавцям, але і групам за статусом. Тобто таким, які мають ряд схожих характеристик та параметрів серед, яких можуть бути посада, відділ, відповідальність та ін.

Завдяки даним особливостям системи документообігу мають можливість надавати права на документи. Організація доступу виконується за рахунок структуризації папок для збереження файлів та документів. Особливістю створення кожного документа, як уже зазначалось, є надання документу індивідуального номеру. Це забезпечує можливість вести супроводжувальну документацію та кореспонденцію. У випадку редагування, створюється новий екземпляр документа з новою датою, відомостей про автора, що забезпечує його цілісність у випадку пошкодження. Реєстраційний номер, реквізити та внутрішня інформація в подальшому використовуються в процесі пошуку [8,9].

Крім фрункціональних можливостей такі системи характеризуються також і технічними. Зокрема доступ до документів може виконуватися паралельно, тобто декілька користувачів одночасно можуть приймати рішення, візувати документ та ін.

СППР в електронному документообігу забезпечує правильність виконання алгоритму та послідовності роботи з документами. Наведені операції супроводжуються збором даних, аналізом структур, моделей, інформації накопичених знань для прийняття правильного рішення в процесі обміну, створення, редагування та управління документами.

\section{Модифікована структура СППР для підтримки документообігу на основі інтелектуального аналізу}

Найпростіший алгоритм дій керівника по управлінню процесами і досягненням цілей відбувається на основі циклу Plan - Do Control - Analysis (P-D-C-A) зображений на рис. 3 [10].

Згідно даної схеми на першому етапі виконується планування. Це сукупність цілей та процесів, необхідних для досягнення мети. До них відноситься виділення та планування необхідних ресур- 


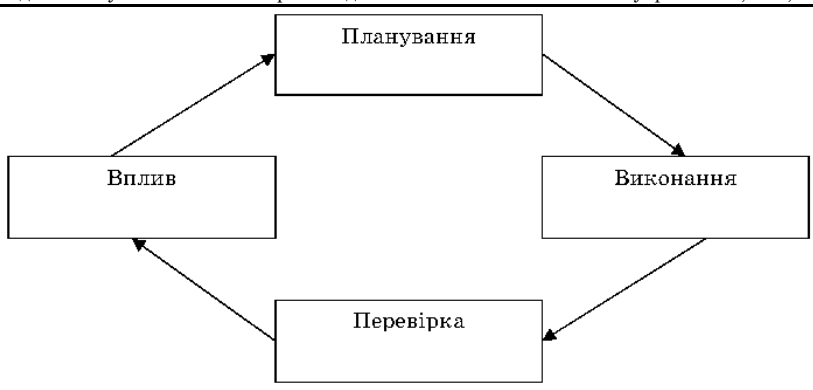

Рис. 3 - Цикл Шухарта - Демінга

сів, постановка мети та цілей, які потрібно досягти для задоволення кінцевого результату та ін. Після цього виконуються заплановані роботи. Результат виконання перевіряеться методом збору інформації основних показників, їхньої ефективності, виявлення відхилень та встановлення причин їхнього виникнення. На основі даного аналізу приймаються заходи щодо усунення причин відхилень відносно запланованого результату, зміни задіяних ресурсів та планування. Цикл повторяеться до того часу поки результат не досягне бажаного.

Отже управління являе собою послідовність пов'язаних процесів та постійної реорганізації згідно поставлених умов. Система підтримки прийняття рішення при цьому оперуе вхідними параметрами, вихідними результатами, інформації про процеси та дозволяе аналізувати зібрану інформацію і прийняти рішення щодо управління для поліпшення його результату.

В процесі документообігу відбувається така ж взаемодія з користувачами системи. Специфіка управління в даному питанні відрізняеться лише об'єктом процесів контролю та аналізу, а саме документів.

Для підвищення ефективності правильності прийняття рішення пропонуеться інтеграція підсистеми інтелектуального аналізу рис. 4. Це механізм СППР, який дозволяе виконати налаштування та підстановку параметрів системи управління. Процес характеризується інтелектуальними ознаками у зв'язку з можливістю саморозвитку, самонавчанням і саморегуляцією системи. Обробка інтелектуального документообігу має на увазі класифікацію, виділення знань з неструкторизованої інформації та накопичення і обробка статистичних даних, зокрема таких які виникли підчас узгодження документів та службової переписки.

Інтелектуальний аналіз СППР містить знання про структуру, шаблони, маршрути схем руху документів а також лінгвістичну особливість, знань про об’ект, задачі та процеси управління. 


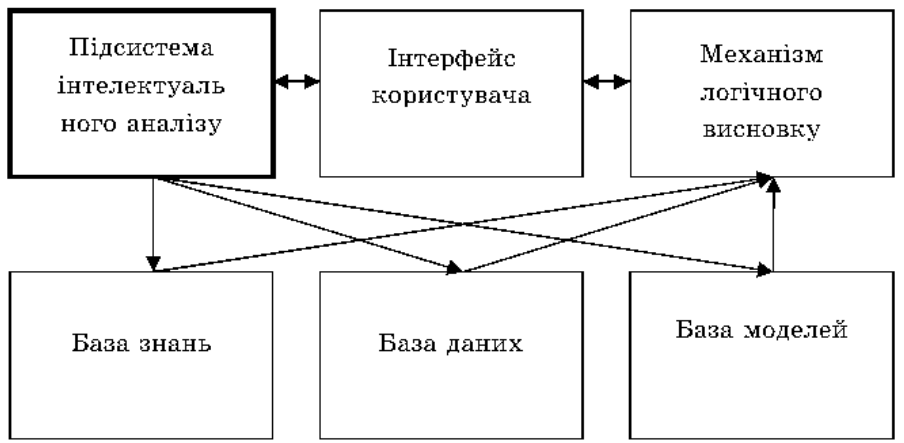

Рис. 4 - Інтелектуальна підсистема СППР

Процес навчання системи прийняття рішення починається з виділення та підготовки даних. По завершенню даного етапу управління на себе бере сама система підтримки прийняття рішення і виконуе виділення ознак та класифікацію вхідної інформації. На основі цього підбирається найкращі методи та будується модель. Існуе велика кількість моделей представлення знань, які можна класифікувати на: продукційні моделі - такі, які грунтуються на правилі виконання дій при певних умовах, семантичні мережі моделі пошуку відношення на основі орієнтованих графів, фрейми - формалізована модель для відображення образу, формальні логічні моделі, процедурні моделі - процедурні, алгоритмічні моделі тобто такі які мають певну послідовність виконання обчислення, прогнозування та ін.

Основною складовою систем прийняття рішення є механізм логічного висновку. Він являеться “мозком” системи, як правило його розглядають як перекладача, який обробляе вхідні дані на основі бази знань та бази даних. Це логічний компонент, що виконуе пошук знань та формування висновку використовуючи моделі. Також у випадку відсутності інорормації здатний добувати їі шляхом опитування користувача, або проводячи додаткові експерименти.

Для забезпечення уточнення знань, накопичення їх в базі знань і вставки нових відомостей отриманих в процесі придбання знань було запропоновано підсистему інтелектуального аналізу. Це інструмент налаштування, який включае в себе інтелектуальні технології тобто такі, які здатні визначати зміст даних, знаходити відповідність та ін. До них можуть відноситися нейронні мережі, що дозволяються приймати рішення на основі неповної інформації, формування маршрутних схем, оцінка цілісності та повноти, створення баз даних про прийняття рішень, пошук готових рішень та ін..

Для створення зв'язку користувача з підсистемою інтелектуаль- 
ного аналізу та механізмом логічного висновку використовується графічний інтерфейс користувача (GUI), що забезпечує інтерактивне середовище для роботи. Заповнення бази знань є однією з найбільш важливим у розвитку системи підтримки прийняття рішення. Інтелектуальний аналіз даних дозволить накопичити набагато більше інформації про процес управління та приймати рішення на основі уже визначений критеріїв, знань, помилок та ін. і швидше обробляти вхідну інформацію, видаючи кращий результат.

\section{Висновок}

В процесі управління організацією виникає потреба прийняття швидкого рішення, яке інколи основане на великій кількості інформації. В умовах розвитку сучасного бізнесу керівник та працівники організації повинні оперувати багатьма даними, висновками та знаннями в предметній області. Інколи за прийняття рішення, погодження документів відповідає весь колектив. Тому є необхідність в автоматизації даного процесу для створення зручного та організованого середовища роботи.

В даному випадку приходять на допомогу системи підтримки прийняття рішень (СППР), які дозволяють надати якісну оцінку ситуації, статистичні дані та багато іншого для узгодження всіх запитань в процесі управління. Для пришвидшення виводу та збільшення достовірності результату СППР було запропоновано інтеграцію інтелектуальних підсистем, які б незалежно від користувачів накопичували знання тим самим навчаючи систему правильно реагувати в певних ситуаціях і на основі попередніх спостережень уміти самостійно примати рішення.

\section{Біблиографічний список}

1. Ларичев О.И., Петровский А.В. Системы поддержки принятия решений. Современное состояние и перспективы их развития. // Итоги науки и техники. Сер.Техническая кибернетика. - Т.21. М.: ВИНИТИ, 1987

2. Marakas G.M. Decision support systems in the twenty-first century. Upper Saddle River, N.J.: Prentice Hall, 1999.

3. Keen, Peter; (1980), "Decision support systems : a research perspective". Cambridge, Mass. : Center for Inf ormation Systems Research, Afred P. Sloan School of Management

4. Davis G. Management Inf ormation Systems: Conceptual Foundations, Structure, and Development. - New York: McGraw-Hill, 1974.

5. Осипов Г.С. Лекции по искусственному интеллекту - 2009, издво "Красанд", 261 с.

6. Томашевський O.М., Цигелик Г. Г., Вітер М. Б., Дудук В. I. К. Інформаційні технології та моделювання бізнес-процесів : навч. посіб. / Центр учбової літератури, 2012. - 296 с. 
7. Будагьянец М.А. Принципы формирования бизнес-процессов

8. Осипов Г.С. Лекции по искусственному интеллекту - 2009, издво "Красанд", 261 с.

9. Сараев А.Д., Щербина О.А. Системный анализ и современные информационные технологии // Труды Крымской Академии наук. - Симферополь: СОНАТ, 2006. - С. 47-59

10. Репин В.В., Елиферов В.Г. Процессный подход к управлению. Моделирование бизнес-процессов. - М.: РИА "Стандарты и качество", 2008. - 408 с.

Отримано 24.10.2013 p. 